\title{
Why New Business Development Projects Fail: Coping with the Differences of Technological versus Market Knowledge
}

\author{
J. Henri Burgers, Frans A.J. Van Den Bosch and Henk W. Volberda
}

\begin{tabular}{|l|l|}
\hline \multicolumn{2}{|l|}{ ERIM REPORT SERIES RESEARCH IN MANAGEMENT } \\
\hline ERIM Report Series reference number & ERS-2007-072-STR \\
\hline Publication & October 2007 \\
\hline Number of pages & 40 \\
\hline Persistent paper URL & \\
\hline Email address corresponding author & hburgers@rsm.nl \\
\hline Address & Erasmus Research Institute of Management (ERIM) \\
& RSM Erasmus University / Erasmus School of Economics \\
& Erasmus Universiteit Rotterdam \\
& P.O.Box 1738 \\
& 3000 DR Rotterdam, The Netherlands \\
& Phone: $\quad+31104081182$ \\
& Fax: $\quad+31104089640$ \\
& Email: info@erim.eur.nl \\
& Internet: $\quad$ www.erim.eur.nl \\
\hline
\end{tabular}

Bibliographic data and classifications of all the ERIM reports are also available on the ERIM website: www.erim.eur.nl 


\section{ERASMUS RESEARCH INSTITUTE OF MANAGEMENT}

\section{REPORT SERIES \\ RESEARCH IN MANAGEMENT}

\begin{tabular}{|l|l|}
\hline ABSTRACT AND KEYWORDS \\
\hline Abstract & $\begin{array}{l}\text { Managing through projects has become important for generating new knowledge to cope with } \\
\text { technological and market discontinuities. This paper examines how the fit between the creation } \\
\text { of technological and market knowledge and important project management characteristics, i.e. } \\
\text { project autonomy and completion criteria, influences the success of new business development } \\
\text { (NBD) projects. In-depth longitudinal case research on NBD-projects commercialised during the } \\
\text { period 1993-2003 in the consumer electronics industry highlights that project management } \\
\text { characteristics focusing only on the creation of technological knowledge contributed to the failure } \\
\text { of those NBD-projects that required new market knowledge as well. The findings indicate that } \\
\text { senior management support and engaging in an alliance with partners possessing } \\
\text { complementary market knowledge can offset this misalignment of the organisation of NBD- } \\
\text { projects. }\end{array}$ \\
\hline Free Keywords & $\begin{array}{l}\text { project management, new business development, exploitation-exploration, knowledge, new } \\
\text { product development, strategic alliances, sales force }\end{array}$ \\
\hline Availability & $\begin{array}{l}\text { The ERIM Report Series is distributed through the following platforms: } \\
\text { Academic Repository at Erasmus University (DEAR), DEAR ERIM Series Portal } \\
\text { Social Science Research Network (SSRN), SSRN ERIM Series Webpage } \\
\text { Research Papers in Economics (REPEC), REPEC ERIM Series Webpage }\end{array}$ \\
\hline Classifications & $\begin{array}{l}\text { The electronic versions of the papers in the ERIM report Series contain bibliographic metadata } \\
\text { by the following classification systems: } \\
\text { Library of Congress Classification, (LCC) LCC Webpage } \\
\text { Journal of Economic Literature, (JEL), JEL Webpage } \\
\text { ACM Computing Classification System CCS Webpage } \\
\text { Inspec Classification scheme (ICS), ICS Webpage }\end{array}$ \\
\hline
\end{tabular}




\title{
Why New Business Development Projects Fail: Coping with the Differences of Technological versus Market Knowledge*
}

(Final Version September 25, 2007)

\author{
J. Henri Burgers \\ Frans A.J. Van Den Bosch \\ Henk W. Volberda \\ RSM Erasmus University \\ Department of Strategy and Business Environment \\ Erasmus University Rotterdam \\ P.O. Box 1738, 3000 DR Rotterdam, the Netherlands \\ Phone: +31.10.408.1126 \\ Fax: + 31.10.408.9013 \\ E-mail: hburgers@rsm.nl; fbosch@rsm.nl; hvolberda@rsm.nl \\ www.strategyaterasmus.nl
}

\begin{abstract}
Paper accepted for publication in Long Range Planning, vol 40, 6 (2007)

Special issue "Managing through Projects in Knowledge-Based Environments"
\end{abstract}

* We gratefully acknowledge the participation of ELECTRA for our case research, and their management's constructive comments on previous drafts of our case analysis. We also express our gratitude to the editors of the special issue and LRP, the three anonymous reviewers, Paul Vlaar, Pieter-Jan Bezemer, participants of a workshop held at Cass Business School, London, March 27, 2006, and of a seminar on NBD-projects organised by the Dutch Association of Business Development Project Managers at the RSM Erasmus University, 25 April 2006 for their suggestions on improving the paper. 
J. Henri Burgers is a research associate at the Department of Strategic Management and Business Environment of the RSM Erasmus University and conducts research in the area of new business development projects and corporate entrepreneurship. He has published in a book and a Dutch academic journal. For further information: www.rsm.nl/hburgers

Frans A.J. Van Den Bosch is a full professor of Management Interfaces between Organisations and Business Environment at the Department of Strategic Management and Business Environment of the RSM Erasmus University, and is chairman of the Programme Board of the Erasmus Research Institute of Management. He has published several books and articles in journals including Academy of Management Journal, Corporate Governance, Journal of Management Studies, Long Range Planning, Management Science, Organization Science, and Organization Studies. He is an editorial board member of among others Journal of Management Studies and Long Range Planning. For further information: www.rsm.nl/fvandenbosch

Henk W. Volberda is full professor of Strategic Management and Business Policy, chair of the Department of Strategic Management and Business Environment, and vice-dean at the RSM Erasmus University. He has published widely in journals such as Academy of Management Journal, Journal of Management Studies, Long Range Planning, Management Science, Organization Science, and Organization Studies. He is senior editor of LRP and JIBS, and member of the editorial board of Journal of Management Studies, Organization Science and Org. Studies. His research on organisational flexibility and strategic change received several awards, including the prestigious Igor Ansoff Strategic Management Award 1993. For further information: www.rsm.nl/hvolberda 


\title{
Why New Business Development Projects Fail? Coping with the Differences of Technological versus Market Knowledge
}

\begin{abstract}
Managing through projects has become important for generating new knowledge to cope with technological and market discontinuities. This paper examines how the fit between the creation of technological and market knowledge and important project management characteristics, i.e. project autonomy and completion criteria, influences the success of new business development (NBD) projects. In-depth longitudinal case research on NBD-projects commercialised during the period 1993-2003 in the consumer electronics industry highlights that project management characteristics focusing only on the creation of technological knowledge contributed to the failure of those NBD-projects that required new market knowledge as well. The findings indicate that senior management support and engaging in an alliance with partners possessing complementary market knowledge can offset this misalignment of the organisation of NBDprojects.
\end{abstract}

Keywords: project management; new business development; exploitation-exploration; knowledge; new product development; strategic alliances; sales force 


\section{Introduction}

In today’s fast-paced, knowledge-based environments competitive advantages erode at an ever-increasing rate. Companies need to continuously develop new business opportunities to tackle technological and market discontinuities. However, the managerial and organisational structures of most firms are primarily catered towards exploitation activities like refining products and processes. These structures do not support the requirements for exploring new business opportunities. ${ }^{1}$ Managers therefore increasingly use projects to create new businesses.

A key aspect of New Business Development (NBD-) projects is the management of knowledge. ${ }^{2}$ Research has shown that project success is enhanced if project management characteristics are aligned with the project's activity. ${ }^{3}$ Previous studies have made a distinction between projects that develop exploitative or incremental innovations versus exploratory or radical innovations. ${ }^{4}$ Radical innovations require both new technological knowledge and new market knowledge, while incremental innovations use and leverage existing technological and market knowledge. ${ }^{5}$

However, Danneels suggested that an important distinction should be made between technological and market knowledge, as it has been argued that NBD-projects might create one type of knowledge and leverage another type of knowledge. ${ }^{6}$ Technological knowledge refers to knowledge associated with products, technologies and/ or processes. Market knowledge refers to knowledge associated with targeting customer sets, entering markets, distribution channels, marketing approaches, and business models. ${ }^{7}$ New business development is the process of linking the technological and market knowledge together. ${ }^{8}$ Although the two types of knowledge are intertwined, their project management requirements and implications for the wider organisational context could differ (see Exhibit 1). ${ }^{9}$ 
Insert Exhibit 1 here

The distinction between the newness of technological and market knowledge is important for at least two reasons. First, both types of knowledge reside in different departments (R\&D versus marketing/ sales). This might have consequences for the autonomy of projects in terms of leveraging knowledge. Second, the timing of development differs for both types of knowledge. Knowledge creation involves learning-by-doing. ${ }^{10}$ Yet, experimenting with market approaches and distribution channels will take place after market introduction, while practicing with products and technologies is done before market introduction. This suggests that project completion criteria might be different for creating technological versus market knowledge.

Given the limited insight in the consequences of technological and market knowledge for NBD-projects, we will address the following research question: How does creation of technological and market knowledge influence project management characteristics of NBDprojects? By doing so, we address the role of projects as focal points of knowledge creation and integration and provide insights into the conditions for the successful management of NBDprojects. We focus our longitudinal research on new business development projects in a large incumbent firm in the consumer electronics industry.

Our findings highlight that technological and market knowledge should have a different effect on project autonomy. By doing so, we extend previous research that has focused on the distinction between exploitative versus exploratory innovations and its effect on project 
autonomy. ${ }^{11}$ Second, building upon Danneels' work, we show the timing and duration of development differs between market and technological knowledge. ${ }^{12}$ Our findings indicate that the creation of market knowledge is likely to continue after market introduction, i.e. during the commercialisation phase. Extending the managing-through-projects approach to the commercialisation phase enhances the success of NBD-projects requiring new market knowledge. Third, our research shows that two strategies can be applied to off-set deficiencies in project management. Top management support can be used to prolong the project approach and to shield the project from organisational pressures to exploit. Our findings also indicate that strategic alliances with partners possessing complementary market knowledge significantly shorten the time to acquire new market knowledge for NBD-projects.

\section{Literature review}

Innovation is not only the creation of new knowledge, but also the recombination with existing knowledge. ${ }^{13}$ The processes of creating new knowledge versus leveraging existing knowledge are referred to as exploration and exploitation. Exploration is the act of creating knowledge that is new to the firm through activities such as experimentation, innovation, search and variation. Exploitation is the act of using knowledge existing in the firm and is associated with implementation, efficiency, production and refinement. ${ }^{14}$ NBD-projects call for both the exploration and the exploitation of knowledge. ${ }^{15}$ Exploration and exploitation require, however, different styles of management and organisational arrangements. ${ }^{16}$

Several studies have been investigating how to manage the creation and transferring of knowledge in the context of new business development. ${ }^{17}$ Yet, these studies did not take into account the effect the type of knowledge has on managing NBD-projects, even though it has 
been argued that technological and market knowledge have different outcomes for organisations. ${ }^{18}$ The benefits of, among others, cross-functional teams, project autonomy, and stage-gated development processes for the successful management of projects are well established. ${ }^{19}$ This paper explicitly focuses the relationship between project management characteristics and technological and market knowledge. Success rates of NBD-projects are enhanced if project autonomy is aligned with the degree of exploration of projects. ${ }^{20}$ This suggests connecting project autonomy with the degree of exploration of technological and market knowledge. Studies have also shown that exploration and project management practices change over the project's life-cycle. ${ }^{21}$ This suggests linking project completion criteria to the phase in which exploration of technological and market knowledge occurs, as a prime objective of NBD-projects is the creation of new knowledge.

\section{Degree of exploration of technological and market knowledge and project autonomy}

The degree of project autonomy influences to what extent the exploration and the exploitation of knowledge is enhanced. The higher the project's autonomy, the more precedence the project takes over various functional areas and the development of its knowledge base. ${ }^{22} \mathrm{~A}$ high degree of project autonomy stimulates the exploration of knowledge, as it shields the project from organisational inertia and knowledge bases. ${ }^{23}$ At the same time, higher degrees of project autonomy make learning and transferring knowledge between the project and the organisation more difficult, because of the relative distance between the project and organisational units. ${ }^{24}$ Providing low degrees of autonomy to an NBD-project limits the ability to explore new knowledge, but enhances the possibility to leverage existing knowledge and resources from the parent organisation. ${ }^{25}$ Autonomy could, inter alia, be increased by using 
heavyweight leaders, by placing a project in physically distinct location, or by increasing the reporting level. ${ }^{26}$

Figure 1 depicts a conceptual framework of four idealised types of projects linking the degree of technological and market knowledge newness to project autonomy. Projects requiring new technological and market knowledge (see Figure 1, quadrant 1) benefit the most from autonomy, as separating a project from the organisational context facilitates learning within the project. $^{27}$ A typical structure for such radically new projects would be some sort of venture unit. $^{28}$

Insert Figure 1 here

Product improvement projects that exploit both existing technological and existing market knowledge benefit from staying close to the mainstream of the organisation to maximise the potential for leveraging knowledge already present within the firm (see Figure 1, quadrant 4). For these projects a functional or lightweight project type is preferred, which receives very little autonomy. ${ }^{29}$ Project members in this type of project divide their time between ongoing activities in their functional department and the project. As such, these employees are in the best position to leverage relevant knowledge and resources from their functional departments. Several authors argue that NBD-project success is significantly enhanced if projects make use of the firm's existing sales force and distribution channels. ${ }^{30}$ 
Projects exploring technological knowledge and exploiting market knowledge require a medium degree of autonomy (see Figure 1, quadrant 2). These projects need autonomy for the development of technological knowledge, ${ }^{31}$ but need lower degrees of autonomy to exploit the available market knowledge. We suggest, therefore, an intermediate solution with medium degrees of autonomy for the project, which leaves room for both exploitation and exploration.

In a similar vein, projects needing exploration of market knowledge and exploitation of technological knowledge would benefit most from a medium degree of autonomy (see Figure 1, quadrant 3). Too close cooperation with marketing and sales might constrain the project's ability to explore market knowledge, and have a negatively impact on project performance. ${ }^{32}$ This suggests that the NBD-project needing exploration of market knowledge should receive a certain degree of autonomy from sales organisations.

Besides exploring new knowledge internally, NBD-projects could also use strategic alliances to develop the missing knowledge and capabilities. Previous research has shown that partnerships with complementary resources and capabilities increase chances for success and competitive advantage. ${ }^{33}$ Using a partnership could speed up the development process and significantly reduce investment costs. ${ }^{34}$ Furthermore, it could also solve the potential conflict between requirements of technological versus market knowledge in NBD-projects, as partners could be responsible for one type of knowledge, while the project is focusing on the other type of knowledge.

Phase in the NBD-process in which knowledge creation occurs and project completion criteria

Projects are temporary structures created to achieve a certain goal. ${ }^{35}$ This suggests defining clear project completion criteria. NBD-projects have the objective to explore new 
products/ technologies, and/ or explore new markets, for the firm. ${ }^{36}$ Project completion criteria should, therefore, be aligned with the process of the exploration of technological and market knowledge. Scholars have previously argued that NBD-projects end when a newly developed product is introduced on the market. ${ }^{37}$ This view limits the exploration of both technological and market knowledge to the development phase preceding market introduction. We argue, however, the exploration of technological and market knowledge end at different points in time.

Following Thornhill and Amit, we identify three phases in the process of new business development (see Figure 2). ${ }^{38}$ The development phase, ranging from the conception of ideas to the introduction of developed products or services on the market. When products are introduced on the market, the project enters the commercialisation phase, running from market introduction until profitability is achieved (i.e. when cumulative profits surpass investment costs). ${ }^{39}$ The final phase is the business phase, when the project has become a business and is self-sustainable.

Insert Figure 2 here

The exploration of technological knowledge is mainly confined to the development phase, with exploratory technological activities such as prototype and product development, and building the (trial) production line. Before the product is approved for market introduction, the end result of the technological development trajectory in terms of a working product and process are usually tested on aspects such as durability and quality. ${ }^{40}$ At the moment of market introduction the product and production line are technically complete, requiring little additional 
development of technological knowledge. The subsequent commercialisation phase calls for exploitation of technological knowledge in order to increase the efficiency of the production process and to refine the product. Hence, projects needing only the exploration of technological knowledge should be completed after the development phase ending at market introduction (see Figure 1, quadrant 2). ${ }^{41}$

The exploration of market knowledge also starts during the development phase with activities such as gaining knowledge about customer preferences and how to reach and target potential customers (see Figure 2). Yet, exploration requires learning-by-doing, which for market knowledge can to some extent only be learned during the commercialisation phase when products are actually sold. This is a prime difference with technological knowledge creation in which case one can experiment before products are actually sold on the market. The exploration of market knowledge continues during the commercialisation phase, when for example concepts are tested in the marketplace and distribution channels are developed. Based also on customer feedback the market approach might be frequently changed during this phase. ${ }^{42}$ NBD-projects requiring new market knowledge should, therefore, only be completed at the end of the commercialisation phase (see Figure 1, quadrants 1 and 3). At the end of this phase, the project has become self-sustainable and does not need protection of top management or a set of special criteria to further explore market knowledge. Concluding, the different phases in which exploration of technological and market knowledge occurs (see Figure 2) suggests project completion criteria for NBD-projects should be contingent upon the phase in which exploration of technological and market knowledge takes place (see Figure 1). 


\section{Methods}

The research reported here is based on an in-depth, longitudinal case study of new business development projects at the DOMUS division of ELECTRA ${ }^{\mathrm{i}}$, a major manufacturer of consumer electronics. By selecting projects within a single division, we were able to reduce potential confounding effects of the industry and the firm. This allowed us to best observe our phenomena of interest, namely how the creation of technological and market knowledge and project management practices influence the success of NBD-projects. To observe the changes in organisational behaviour over time and to gain deeper understanding of the role of technological and market knowledge creation in managing NBD-projects, we choose qualitative methods instead of quantitative methods. The selected method increases the validity of our study, but at the same time we acknowledge that we might loose possible generalisation to other industry contexts.

The projects were selected based on the exploration of technological and market knowledge (see Figure 3). All projects needed to have reached the commercialisation phase. To measure the degree of exploration we first asked respondents to what extent the product/ technologies and markets were existing to the firm, new-to-the-firm, -industry, or -world. Second, we asked them to explain what aspects where new, because something that is new to the firm does not necessarily involve much exploration. For example, a firm can enter a new market segment, but might use existing distribution channels and market approaches. Third, we investigated company documents to look for statements on actual explorative behaviour. For example, if minutes of meetings stated that the project team was developing medical knowledge to sell their products through pharmacies as opposed to electronic retail stores, this would be classified as exploration of market knowledge (see also Table 1). Using multiple sources of

\footnotetext{
${ }^{\mathrm{i}}$ Due to confidentiality agreements, we changed the name of the company.
} 
evidence allowed us to develop a more fine-grained measure of the degree of exploration needed than would be possible through survey research.

We used several rounds of data collection and a variety of internal company documents like minutes of meetings and business plans, and external documents to analyse the projects. Additionally, we interviewed several key project members, division executives, R\&D directors, and sales managers for the projects to triangulate the findings with different sources. Appendix 1 provides more detail on our research methods.

Insert Figure 3 here

\section{Research setting}

ELECTRA is a large multinational company that consists of several relatively autonomous product divisions. Besides the product divisions, national and regional sales organisations were part of the company. Because many of DOMUS' products are sold through the same retail stores, a single sales person of DOMUS offers the whole range of DOMUS' products to a retail store instead of having different sales persons for each product line.

At the time of investigation, DOMUS consisted of a business group focusing on household products and one focusing on personal care products. The business group of household products had a diverse product portfolio, mostly in increasingly saturated markets. Market growth had slowed down to around 2-3 percent and there was an increasing trend towards commoditisation. Sales growth was mainly achieved through market share battles, but 
management recognised opportunities for entering new markets and for radically redefining existing product/market propositions. The business group of personal care products consisted of a rather narrow, but highly profitable product portfolio that was also confronted with decreasing sales growth. Yet, the opportunities for boosting growth were markedly different, as growth opportunities were primarily in addressing new product categories.

DOMUS consisted of several business units that each contained a few business lines, which consisted of one or more product lines. Units were defined based on relatedness of product (categories). The business units were responsible for NBD-activities. The NBD-project managers reported to a business line manager within these business units. NBD-projects within DOMUS were cross-functional, and included both engineers as well as marketers. DOMUS used heavyweight projects for the NBD-projects we investigated, but with relatively junior managers leading the projects. The engineers and marketeers were assigned fulltime to a project, and had clear responsibilities toward the project manager, although they formally reported to their functional units. The projects were organised and the development activities executed according

to a standardised approach that was described in a manual. A senior project manager of Skin pointed out: “...we followed a very strict process, which was actually a best-in-class process with all the stages, gates, and milestones, but this was very much driven from the [technological] development side. On the marketingside it was very loose.”

\section{Case study findings}

We investigated eight NBD-projects within DOMUS. These projects were executed during the period 1993-2003. Table 1 presents an overview of the investigated projects. Project Drink developed a segment of an existing market, while others targeted a market completely new for ELECTRA (projects Health and Skin), or focused on markets that were geographically 
relatively new for ELECTRA (project Cook). Several projects (Drink, Oral, and Health) made use of an alliance to build the new business. All projects fitted within the defined strategy of DOMUS to manufacture mass electronic consumer goods for household or personal care use. The projects in our sample provided significant revenues. Projects Hair and Air achieved over 30 million euros in annual turnover two years after market introduction, while project Drink has sold millions of products in the first four years after market introduction. Projects Fem and Oral have grown into businesses with annual sales well exceeding 100 million euros.

Insert Table 1 here

Degree of exploration of technological and market knowledge and project autonomy

In the case of the exploration of technological knowledge, previous research suggests a heavyweight project-type is preferred. ${ }^{43}$ Projects Fem and Hair grew into successful businesses by adopting this structure. All investigated projects and businesses within DOMUS were in the area of consumer electronics, suggesting relatively similar technological bases. This allowed project teams to build on the capabilities of the engineers to create electronic products for household use. The heavyweight structure provided projects with sufficient autonomy to create new knowledge, while the project was still sufficiently integrated with other units to leverage existing capabilities. The projects used employees from the R\&D departments which further facilitated the access to relevant knowledge and capabilities. Project Cook received more autonomy than the other investigated projects. Instead of the standard approach of developing the 
project at one of the operational business units, project Cook was situated in Asia. This limited project Cook's access to organisational knowledge and support, as the project was far away from the company's business units in Europe. As a result, the project had to develop many of the competencies regarding manufacturing and testing the product itself. It did not draw on employees from R\&D departments, but hired new personnel. This resulted in long lead times and poor initial product quality, which had adverse effects on the project's performance.

Although the projects' degrees of autonomy were adequate for the exploration of technological knowledge, it did create problems for the exploration of market knowledge. Most projects operated autonomously from the sales organisations. A sales manager pointed out: "The BU sometimes developed things without full commitment and involvement of the sales organisations. There was a somewhat isolated attitude, in the sense of wait until it is finished and we'll show you. Here and there were some walls in the organisation over which something was thrown from time to time.” The task of NBD-projects was to explore what should be done regarding the market, in terms of new distribution channels and new marketing approaches. The sales organisations were responsible for exploitation in the sense that they had to sell the products through the new distribution channels etc. The sales representatives had, however, neither the time nor the resources to learn how to sell the developed product through new distribution channels. The projects received time and resources to search new knowledge, but sales employees did not receive time and resources to learn and practice. In an interview a business manager of Oral pointed out: "An important market for Oral was country X. The average age of the sales employees was around 50 and they had been selling kitchen appliances for 25-30 years. Could we ask of these sales employees to suddenly have a talk with specialists about inter-dental cleaning?" This proved to be too difficult and currently project Oral still has its own sales force and is managed autonomously from other business units. 
Several projects tried to compensate for their lack of market knowledge by engaging in an alliance with a partner possessing the required market knowledge (see Table 1). The business manager of Project Oral continued: "That's one of the reasons we established the alliance and did the acquisition. It proved too difficult to build up our own competences and network regarding professional endorsement by medical specialists." The alliance partner did have the competences and network. There was, however, some overlap on the technological side, which led to disputes between both parties on how certain parts should be constructed and who should develop it. Combined with the somewhat diverging interests and the lack of alliance experience of both companies, this led to disbanding the alliance. Project Drink’s alliance, however, was a major success. Project Drink used a new business model in which revenues from so called consumables were the main profit drivers instead of the core product (recall Polaroid's razor/blade strategy discussed in the theory section in which camera prices were kept low to stimulate demand, while the profit was made on the film, i.e. the consumable). But project Drink had limited experience with selling and marketing these consumables. The partner did have a background in these consumables and took care of developing and selling the consumable, while project Drink handled the development and selling of the core product. This complementarity made them ideal partners. Establishing the alliance was, however, a slow and painstaking negotiation process, because of the limited experience of DOMUS with such alliances. The success of this alliance contributed to the establishment of a corporate alliance office to capture and leverage knowledge on establishing alliances.

Concluding, the autonomy of the project influenced to what extent projects were able to explore technological and market knowledge, and benefit from knowledge already existing in the firm. As suggested by the case study, a heavyweight project placed within the operational business units provides sufficient autonomy to develop new products, but is still able to leverage 
relevant technological knowledge and capabilities. If a project receives more autonomy (e.g. Project Cook) it needed more time to develop technological knowledge, as it could not draw on available knowledge, skills, and personnel. Regarding market knowledge, however, the investigated projects were too autonomous from the relevant sales organisations. By not being involved in the project, the sales organisations did not receive the time and resources to develop and experiment with novel market approaches. The case study indicates that strategic alliances are useful to decrease the time it takes to acquire new market knowledge and the time to achieve profitability. Projects Drink and Oral demonstrate the impact of such alliances, as they became major successes, while other projects exploring market knowledge (Air, Skin, and Cook) continued their struggle to find the right approach towards the market.

Phase in the NBD-process in which exploration occurs

A major difference between technological and market knowledge is when the exploration takes place. In our case study, the exploration of technological knowledge took place before market introduction. The product development ended with exposing the products to durability tests, which were performed before introduction on the market. Production processes were constructed and many trial runs were done before the project was given the green light to start manufacturing for first sales. Most projects benefited from testing facilities and capabilities the company already possessed. For projects Oral, Cook and Health existing tests were not applicable. A project manager of project Oral stated: “A lot of our standard tests were designed for a kitchen environment. Our product was however used in a bathroom, in which the atmosphere is warmer and moister. We had to learn how to test for this." Project Cook faced similar problems, as it had to build up testing competencies in Asia. Despite difficulties with testing the product, these projects continued with 
market introduction. The pressure to launch quickly led projects Cook, Health and Oral to prematurely introduce the products on the market, resulting in high recall rates for their products.

The exploration of market knowledge also started during the development phase (see Figure 2). A project manager of project Skin commented on the market research: "It is a new business, how do you know how many we can sell? You can improve your guessing with more and better customer research and knowing how to understand the numbers. The problem was that we did not know how to interpret the numbers we got back, as we had no data to compare it to." This lack of understanding of the market led to flaws in the project's assumptions, product positioning and business model, which came to the surface during the commercialisation phase. In an interview, the project manager of Skin stated: "Two of the major reasons that brought Skin down were marketing and distribution. We found out that the average time it took a consumer to decide to purchase our product was three months, while for the average product DOMUS sold it is more in the area of two days. During that three month period you have to get your message out and convince potential consumers, as they will ask everybody from their friends to their doctor what they think of the product.” A former business manager of Oral also stressed the exploration of market knowledge still taking place: "The traditional way of DOMUS for a market introduction campaign was to execute just one brief mass marketing campaign and that is it. We had to learn that we regularly had to contact medical specialists to achieve professional endorsement.”

From the case analysis it appears there was hardly any time left to create the required market knowledge once products had been introduced on the market, due to the imposed project completion criteria. During the commercialisation phase projects were managed according to criteria similar to managing existing businesses within DOMUS. First, projects had to use a mass-introduction strategy in multiple countries, which a project manager labelled the "do-it-rightthe-first-time approach”. A second criterion was that NBD-projects had to achieve profitability within 2 years, i.e. investment costs should be earned back within this 2-year period. A third criterion stated that projects needed to use their own revenues if they wanted to make additional 
investments in exploration once products had been introduced on the market. In other words, projects were considered to be completed at the moment of market introduction. During the commercialisation phase these activities were viewed as emerging businesses, which were granted two years to achieve profitability levels comparable to other businesses. A project manager of Cook pointed out: "we performed relatively well on the milestones in the development phase, but that is one of the strengths of DOMUS. The bigger project Cook, however, was not handled in a project-like way. That was more the running of a daily business.”

Of the eight investigated projects, Fem and Hair were the only two projects that did not need significant exploration of market knowledge (see Table 1 and Figure 3). These projects became instant successes, as they benefited from leveraging existing market knowledge bases. The criteria to view the project as completed at market introduction were aligned with the exploration of technological knowledge, which took place before market introduction.

Out of the six projects that required exploration of market knowledge, only two projects became a success. The four failing projects were seriously constrained by the before-mentioned business criteria imposed on them during the commercialisation phase. Project Air, for example, used a mass-introduction strategy on multiple markets. After market introduction, the project experienced several problems with the business model, marketing approach and distribution channels. As a consequence, demand was far lower than expected and $80 \%$ of the production capacity remained unused. The project either needed significant investments to turn the tide or needed to write off the initial investments and continue on a smaller scale. Yet, the criteria imposed by top management did not allow these options, as projects only got two years to become profitable and were not entitled to financial support.

The two successful projects (Drink and Oral) managed to offset these project completion criteria that were not aligned with exploration during the commercialisation phase. Project Drink 
used an alliance for the exploration of market knowledge, i.e. the business model and market, and more importantly used a single test market to further explore if the developed product propositions and marketing campaigns are effective. In an interview an R\&D manager pointed out: "What worked very well was using a single test market. It created success, which worked positively towards other markets. The idea was to keep it small, learn and use the experience gained in other markets. Once you have success it is easier to convince management to invest additional resources for launch in other countries.” The marketing manager of project Drink explained the exploration of market knowledge: "through project Drink we learned how to do this. Just testing it in the market and learn about optimal product positioning, marketing strategies and then executing it on a larger scale.” The number of products sold during the first year was three times higher than the most positive scenario, which shows the advantage of a project approach over a business approach in the case of exploration of market knowledge during the commercialisation phase.

Project Oral became a success after almost 10 years of experimentation, learning, and development, resulting in significant investments and losses. The project completion criteria that were established for NBD-projects that reached the commercialisation phase (i.e. becoming profitable in two years) were, however, overruled by the responsible business manager. In an interview, a former project manager of Projects Air and Cook commented: "One of the most important things is creating the right environment and support for the new business. In personal care for example they committed themselves if they spotted an important opportunity. A good example is project Oral. The first five years were basically a disaster. Everybody in the organisation yelled that we should stop, as our product quality was inferior compared to the competition. But there was one manager who said these comments were fine and all that, but the project would continue.” The champion had sufficient authority and resources at his disposal to actually allow the project to continue. Other projects needing additional time to develop the markets also had champions, but the problem was that these champions moved to positions in 
other BU's or divisions due to job rotation mechanisms. The project manager continued: “Then you see the importance of a long-term champion. He was in that business unit for many years, while for other projects, every couple of years a new business manager arrived."

Several projects also found that in order to succeed in developing new markets, the sales organisations had to explore new ways of working. Although the autonomy of the project allowed the projects to explore freely and develop innovative approaches, it did not result in workable situations, as the sales force did not get the time or the incentives to learn how to operate successfully in these new environments. A sales manager commented : "At that time sales employees were not rewarded to introduce new products. Our trade partners received incentives to prioritise certain products, but not internally towards our sales force. Management just provided sales targets for each product.” The consequence was that the sales organisations and the individual sales representatives favoured existing products over new products, as they required less effort to reach the sales targets than new products. Because neither the business units and projects nor the sales organisations received incentives to create the required market knowledge during the commercialisation phase, disputes arose frequently about who should pay for it. Fem, Hair and Drink were perceived as logical additions to the product portfolio and did not receive much resistance from the sales organisations. Cook was also a welcome addition to the product portfolio in the eyes of the sales organisations, but the sales organisations did not have the resources to support the market development for project Cook. On the contrary, one of the objectives of project Cook was to strengthen the sales organisations in Asia, which is the other way around. Projects Health, Skin, Oral and Air stretched the portfolio a bit more, as they all had a medical aspect in their business model, and some were a bit more niche marketing than usual within DOMUS. As pointed out, in particular the medical side with new distribution channels and professional endorsement created major challenges for the sales organisations, but no resources were made available to explore. 
In summary, the used project completion criteria at DOMUS to view a project as a business when the commercialisation phase starts suited the projects primarily needing exploration of technological knowledge, i.e. quadrant 2 in Figure 3. NBD-projects requiring new market knowledge, however, would have significantly benefited from a managing-throughprojects approach during the commercialisation phase. Extending the project approach until profitability is achieved might have led more of these projects to success, because of the available time and resources to develop knowledge about the intended markets. The case study also points to the importance of including sales organisations in the project. This provides the project with access to the available knowledge stock in the sales organisation, and points to the relevance of providing sales organisations with time and resources to explore market knowledge. Our findings indicated that using strategic alliances or top management support could overcome misalignment of project completion criteria with the requirements for new market knowledge.

\section{Discussion of findings: Managing NBD-projects}

The NBD-projects in our sample were managed and organised in accordance with a focus on the exploration of technological knowledge. NBD-projects were placed in operating business units close to $R \& D$ and engineering departments, which gave them good access to technological knowledge. The standardised project management approach treated the NBD-projects as regular businesses after market introduction. This benefited projects that focused on the creation of technological knowledge and did not require new market knowledge (projects Fem and Hair). Projects needing exploration of market knowledge ran into severe problems because they did not receive the autonomy, the resources, and the time necessary to develop market knowledge during the commercialisation phase. ${ }^{44}$ Several NBD-projects requiring market knowledge during the 
commercialisation phase, began cost-cutting programmes and opted for less innovative approaches to achieve profitability within the required two years. Moreover, top management demanded a launch strategy, in which products had to be introduced on many markets at the same time. This type of launch strategy maximises economies of scale, but leaves little time to

experiment with different approaches. ${ }^{45}$ In line with our conceptual framework, the case findings highlight that a single approach towards NBD-projects does not do justice to the diversity of projects in terms of their required exploration of technological and market knowledge.

\section{Managerial implications}

Our findings highlight at least four important implications for senior and project management (see Table 2).

Insert Table 2 here

First, senior and project management have to recognise the differences between the exploration of technological versus market knowledge and match the project's autonomy to the degree of exploration of both types of knowledge (see Figure 1). The degree of autonomy a project receives should increase when there is a greater need for development of technological and market knowledge. Higher project autonomy facilitates knowledge creation in the project, while tighter links between the project and mainstream businesses are beneficial if the project wants to benefit from existing knowledge. ${ }^{46}$ This suggests companies should have a range of 
managerial and organisational arrangements for NBD-activities tied to the specific knowledge requirements of projects, instead of applying one standardised arrangement to all types of projects. ${ }^{47}$ Our case findings pointed out that a standardised approach aligned with exploration of technological knowledge significantly constrained NBD-projects requiring the development of market knowledge.

Second, management should enable the exploration of market knowledge taking place during the commercialisation phase by setting project completion criteria that include this phase in the project (see Figures 1 and 2). This protects the project from increasing business pressures to show early results, and provides them with the opportunity to experiment with new approaches; two key aspects for the success of exploratory projects. ${ }^{48}$ Establishing project completion criteria provides clarity and a point-of-reference to both the organisational context and the project in terms of when exploratory behaviour is expected. ${ }^{49}$ It is, therefore, important to connect the project completion criteria to the timing and duration of the exploration of technological and market knowledge.

Third, senior management support can offset some of these contingencies regarding project completion and autonomy. Figure 1 presents an idealised model that provides sufficient protection from business pressures for each type of project. We argued that a mismatch between autonomy/ completion criteria and knowledge requirements could result in increasing business pressure and higher chance of project failure. Yet, senior management supporters (champions) were able to protect projects from too much pressure. ${ }^{50}$ Project Oral's champion, for example, allowed the project to undertake the necessary exploration even though organisational procedures suggested otherwise. However, support is often not a sustainable solution, as for example job rotation mechanisms can replace champions by new and perhaps less favourable 
managers. ${ }^{51}$ For example, project Air suffered from replacement of their champion. Champions have thus positive effects on NBD-project success, but management should be aware of the potential negative consequences for the project if a champion is promoted or leaves.

Fourth, another way of dealing with the conflicting forces of long development times for market knowledge versus increasing business pressures to show results is the use of strategic alliances to access complementary market knowledge. This significantly reduces development time and costs. ${ }^{52}$ It reduces the need to explore market knowledge during the commercialisation phase, which was one of the main contributors to project failure in our study. In particular if the existing sales force is not equipped for selling the newly developed products, management will have to invest substantial resources to build up a new sales force for the project. Using a strategic alliance (e.g. project Drink) could reduce or eliminate the need to build a new sales force.

Fifth, the case study showed that senior management should devote significant attention to the impact NBD-projects have on the requirements for the company's sales force. In the case of significant exploration of market knowledge, the existing sales force might have to learn new skills to successfully market the new product. If sales employees are judged against exploitative criteria (i.e. the need to achieve a certain amount of sales each year), they have little incentive to invest time and resources selling a product for which success is uncertain. Thus alignment of incentive structures for the sales force with the requirements of an NBD-project is an important factor in the ultimate success of the NBD-project. ${ }^{53}$

\section{Theoretical implications and conclusions}


Several implications for theory also resulted from our findings. Previous studies have shown that project and organisational requirements differ for radical versus incremental innovations. ${ }^{54}$ Radical innovations have been classified as requiring both new technological knowledge and new market knowledge, while incremental innovations use and leverage existing knowledge. We complemented this literature by also addressing projects that either focus on new technological knowledge or new market knowledge (see Figure 1), and show that the managerial and organisational requirements differ for both types of projects.

This more fine-grained description of NBD-projects contributes to knowledge and innovation literature by showing that technological and market knowledge differ in terms of timing when exploratory activities take place. Danneels argued that technological and market knowledge differ in terms of competence bases. ${ }^{55}$ Our findings indicate that exploring new technological knowledge takes place in the development phase preceding market introduction, while creating market knowledge takes for a large part place during the commercialisation phase (see Figure 2). This also points to the importance for more specifically addressing the commercialisation phase in product development and project management research.

Finally, we complement project management literature by addressing the underresearched relation between NBD-projects and their organisational context. ${ }^{56}$ In particular we show that NBD-projects exploring new markets can place significant demands on the company's sales force to such an extent that it triggers organisational renewal. The demand for organisational renewal may be offset by alliance partners possessing complementary knowledge and capabilities. By doing so, we have contributed to the emerging debate on using alliances in NBD-projects. 
Several future research issues also emerged from our findings. A logical next step would be to do large scale cross-sectional research to assess the generalisability of our findings. It would in particular be interesting to investigate the extent to which our findings apply to projectbased firms, projects in the service sector, and to firms in the so-called Complex Products and Systems (CoPS-) projects sectors, which develop unique one-off products and are often built to order. ${ }^{57}$ In the latter case, we expect the order in which both types of exploration takes place would be different, as selling and marketing would precede actual technological development. We invite further research to investigate possible other contingencies regarding the exploration of technological and market knowledge, like the internal organisation of a project and the type of project manager needed.

In conclusion, we have put forward the argument that developing technological and market knowledge have an important impact on managing through projects. Our conceptual framework and case findings provide guidelines to enhance the success of NBD-projects in mass-manufacturing companies. We showed that aligning project autonomy and project completion criteria with the degree of required exploration of technological versus market knowledge is essential for successfully managing new business development projects. 


\section{APPENDIX I Research methods}

Using multiple cases allowed us to replicate our findings and strengthened the validity of

our research. ${ }^{58}$ The cases were selected based on a theoretical sampling logic following our primary object of interest, namely technological versus market exploration in the setting of NBD-projects. In the logic of Figure 1, projects were selected in quadrants 1,2 and 3. Furthermore, we expect the exploration of market knowledge to continue during the commercialisation phase. As such, the selected NBD-projects needed to have reached this phase. Third, the sample had to incorporate both successful and unsuccessful projects. We defined failure in terms of projects that were abandoned and success as projects that became major, profitable businesses - criteria that were only possible due to the long time-span which our study covered (1993-2003).

During the 14-month period (2004-2005) in which the research was carried out we first sat down with management to identify the projects and key persons involved. These persons were approached for interviews and to provide documentation on the projects. Snowball sampling helped us to identify additional contacts. The first round of data collection involved publicly available information and divisional-level documents, such as annual reports, and strategy and budget documents, to gain insight into the situational context at the time of the projects.

The second round of data collection concerned project-specific documents, like minutes of meetings, progress presentations to top management, strategy documents. For each project, the data was categorised into our main variables such as exploration of technological and market knowledge, relations with other parties (inside and outside the organisation), and performance of 
the projects. Based on the documentation, case narratives were written for each project to describe the development of the projects over time.

To provide a richer view of the projects, the third round of data collection included interviews with key project members. We developed an interview guide based on the categories used in the documentation process to cover the main topics. We used open-ended questions to invite respondents to talk about a subject instead of pushing them in a certain predefined direction. The semi-structured interviews lasted around $1 \frac{1}{2}$ hour each and were recorded, resulting in over 200 pages of transcripts. The transcripts were sent back to the interviewees for corrections and additions. In total we conducted 21 interviews (2-3 interviews on average per project). We selected key project members that had a good overview of the entire project and its relationship with the parent organisation (i.e. the project, R\&D and marketing manager). We compared data from different sources to check for potential retrospective biases in our after-thefact interviews. A retrospective bias seemed to be slightly present with employees still working at that division who had participated in an unsuccessful project. The overall description they gave of the projects was similar, but some of these employees had a tendency to blame others for failure of the project. Using documentation and multiple informants allowed us to triangulate findings and control for retrospective biases in our interviews. ${ }^{59}$ The findings from the documents and the interviews were combined in a report on our findings. This report was discussed during a workshop with senior management to assess the validity of our findings. The feedback was included in a final report, which was presented to management. 
FIGURE 1 Conceptual framework: knowledge types and project management characteristics

\section{Technological knowledge}

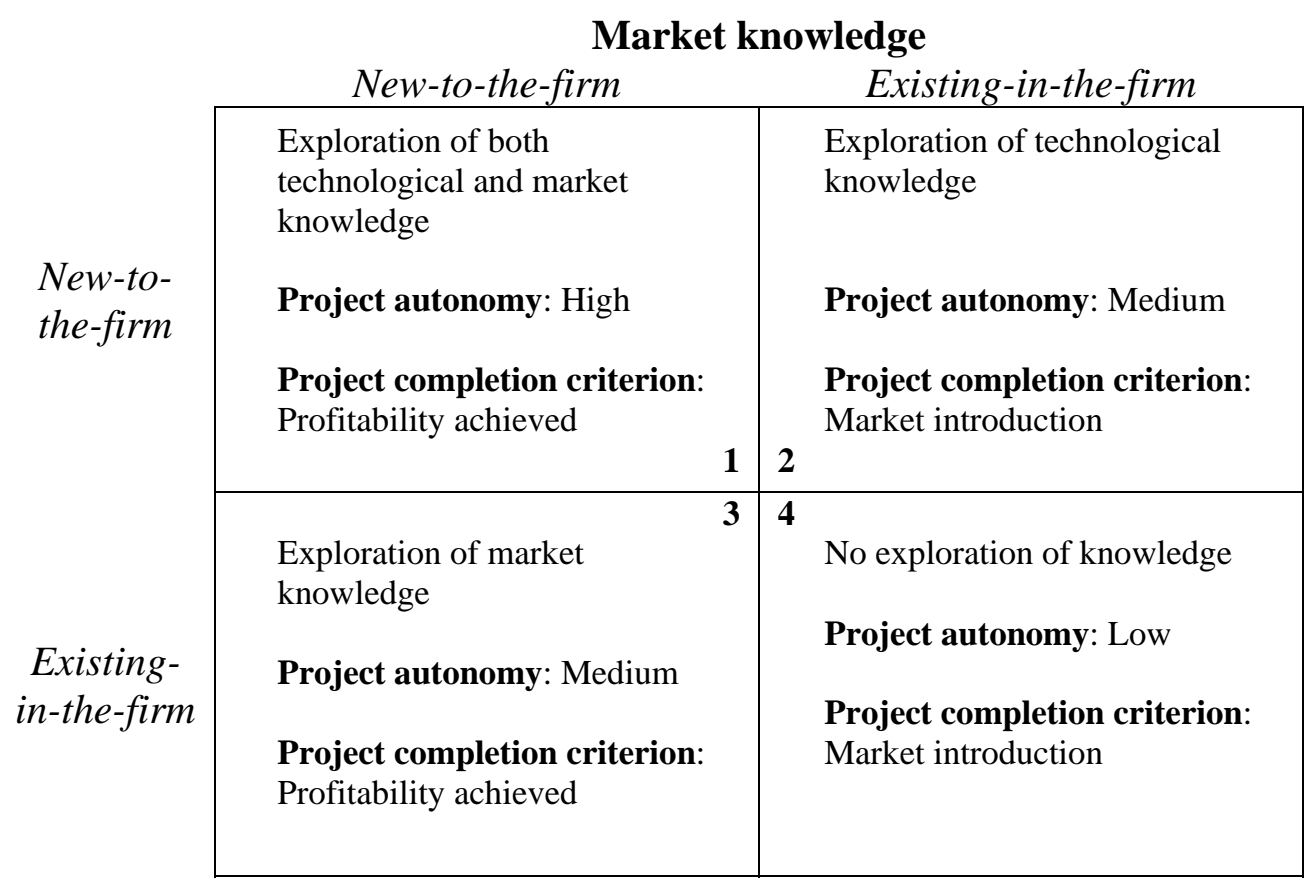


FIGURE 2 Exploration and exploitation of technological and market knowledge in subsequent phases of an NBD-project's life cycle
Development phase
Commercialisation phase
Business phase

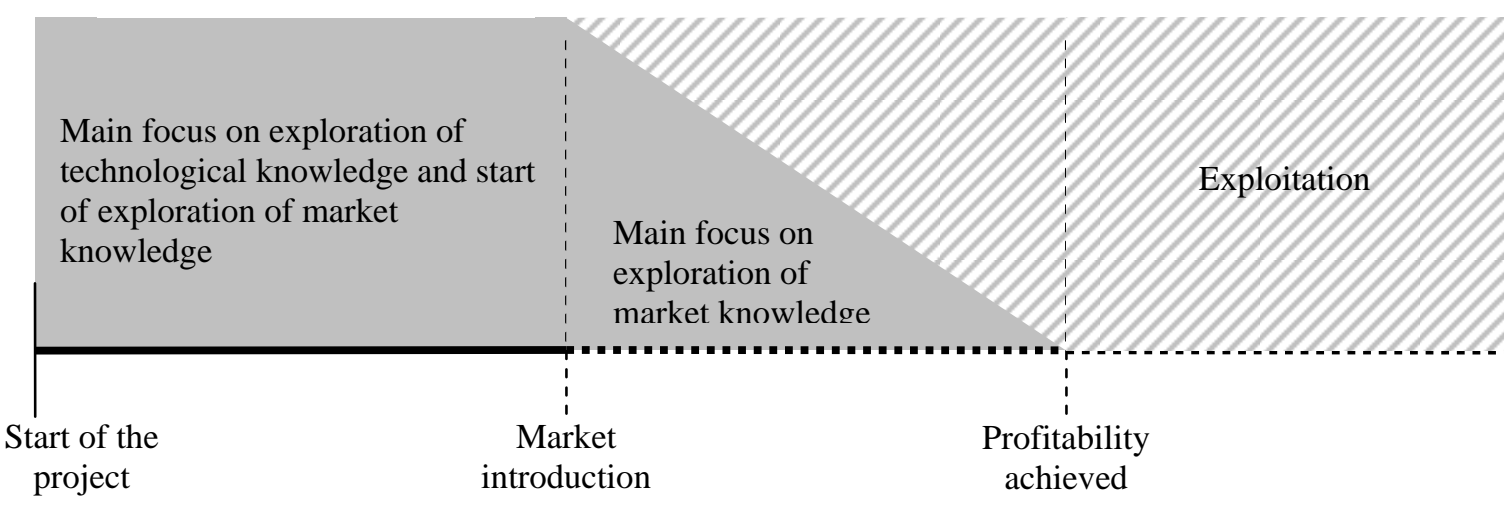

Exploration: creating knowledge new to the firm

I//. Exploitation: using and leveraging knowledge existing in the firm 
FIGURE 3 Classification of the eight investigated NBD-projects

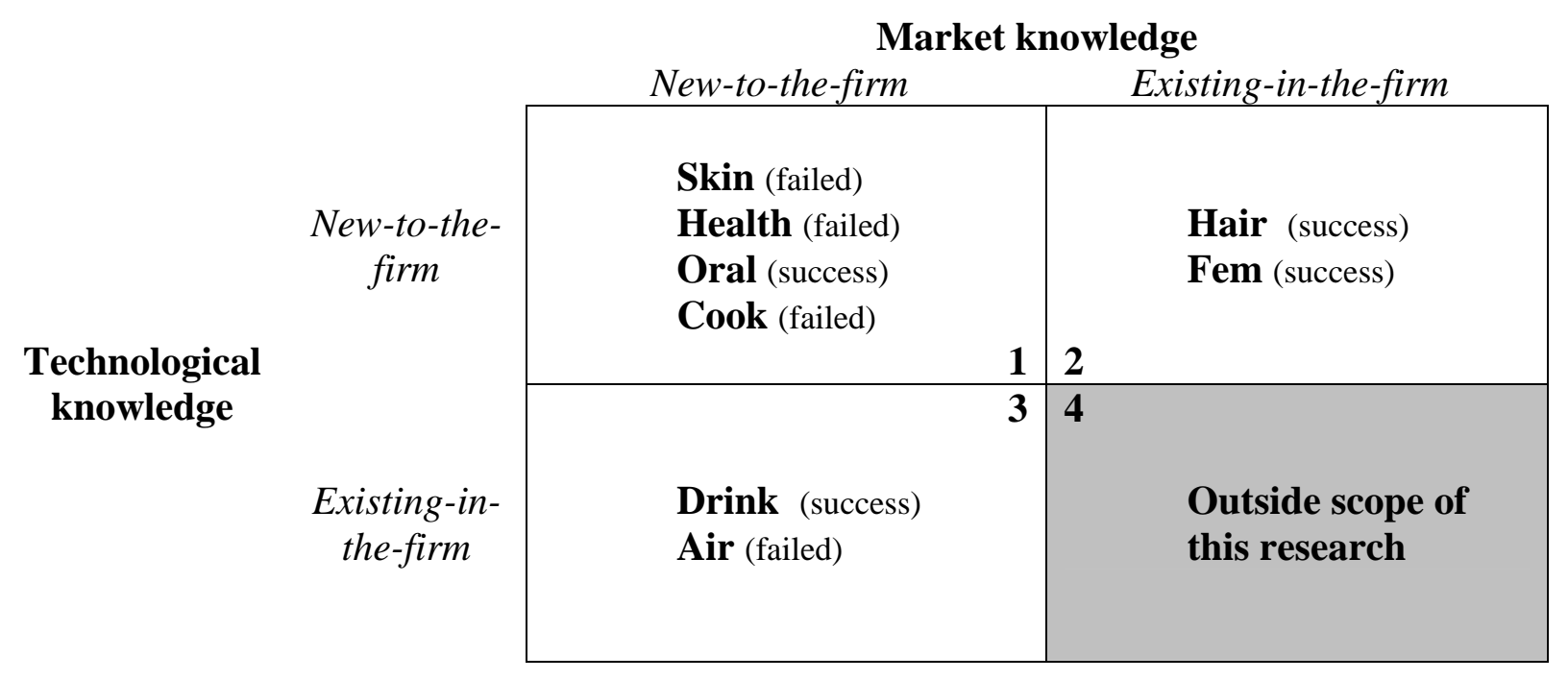


EXHIBIT 1 Technological versus market knowledge: The case of Polaroid and digital photography. ${ }^{60}$

In the 1980s, Polaroid invested heavily in the development of digital technology. Strongly supported by top management, the project developed leading-edge technological capabilities in digital imaging. The company's processes and capabilities were geared towards the development of technological knowledge, which enhanced the successful development of digital imaging capabilities. However, the company did not become successful in digital imaging despite the successful development of technological knowledge. The primary reason was that Polaroid did not recognise the need for the exploration of market knowledge. Polaroid was at that time very successful in instant photography. Its business model was a so-called "razor/blade" strategy, in which the firm dropped prices of the camera to stimulate demand and subsequently made money on the film. However, digital imaging does not use film and as such digital camera's needed new market knowledge in the form of new business models and distribution channels. Polaroid was also confronted with a new set of competitors, as (computer) electronics manufacturers also developed digital imaging capabilities. Due to Polaroid's dominant managerial cognition and inertial ways of working that were strongly tied to their existing market knowledge, the company gradually lost its strengths in digital imaging and failed to capture the market. 
TABLE 1 Knowledge creation and project success in the investigated projects

\begin{tabular}{|c|c|c|c|c|c|}
\hline Project & Newness of technological knowledge & $\begin{array}{c}\text { Development of } \\
\text { technological } \\
\text { knowledge }\end{array}$ & Newness of market knowledge & $\begin{array}{c}\text { Development } \\
\text { of market } \\
\text { knowledge } \\
\end{array}$ & $\begin{array}{c}\text { Status } \\
\text { (duration) }\end{array}$ \\
\hline \multicolumn{6}{|c|}{ Projects exploring technological and market knowledge } \\
\hline Oral & $\begin{array}{l}\text { Product: new-to-the-firm } \\
\text { Technologies: new-to-the-firm } \\
\text { Production processes: new-to-the-firm }\end{array}$ & $\begin{array}{l}\text { Internal, brought-in } \\
\text { expertise, alliance, } \\
\text { acquisition }\end{array}$ & $\begin{array}{l}\text { Market: new-to-the-firm } \\
\text { Distribution channels: new-to-the-firm } \\
\text { Market approach: new-to-the-firm }\end{array}$ & $\begin{array}{l}\text { Internal, alliance, } \\
\text { acquisition }\end{array}$ & $\begin{array}{l}\text { Success } \\
\text { (ongoing) }\end{array}$ \\
\hline Health & $\begin{array}{l}\text { Product: new-to-the-firm/ -world } \\
\text { Technological concept: new-to-the-world } \\
\text { Production processes: new-to-the-firm }\end{array}$ & Internal, alliance & $\begin{array}{l}\text { Market: new-to-the-firm } \\
\text { Distribution channels: new-to-the-firm } \\
\text { Market approach: new-to-the-firm }\end{array}$ & Internal & $\begin{array}{c}\text { Stopped } \\
\text { (after } 3 \text { years) }\end{array}$ \\
\hline Skin & $\begin{array}{l}\text { Product: new-to-the-world } \\
\text { Technologies were leveraged and adapted } \\
\text { Production processes: new-to-the-firm }\end{array}$ & Internal & $\begin{array}{l}\text { Market: new-to-the-industry } \\
\text { Distribution channels: new-to-the-industry } \\
\text { Market approach: new-to-the-industry }\end{array}$ & Internal & $\begin{array}{c}\text { Stopped } \\
\text { (after } 4 \text { years) }\end{array}$ \\
\hline Cook & $\begin{array}{l}\text { Product: new-to-the-firm } \\
\text { Technologies were leveraged and adapted } \\
\text { Production processes: new-to-the-firm. }\end{array}$ & internal & $\begin{array}{l}\text { Market: new-to-the-firm } \\
\text { Distribution channels: new-to-the-firm or } \\
\text { underdeveloped } \\
\text { Market approach: new-to-the-firm }\end{array}$ & Internal & $\begin{array}{c}\text { Stopped } \\
\text { (after } 4 \text { years) }\end{array}$ \\
\hline \multicolumn{6}{|c|}{ Projects exploring technological knowledge and exploiting market knowledge } \\
\hline Hair & $\begin{array}{l}\text { Product: new-to-the-firm } \\
\text { Technologies could be leveraged and adapted } \\
\text { Production processes: new-to-the-firm }\end{array}$ & Internal & $\begin{array}{l}\text { Market: existing, but segment new-to-the-firm } \\
\text { Distribution channels: existing } \\
\text { Market approach: existing }\end{array}$ & Internal & $\begin{array}{l}\text { Success } \\
\text { (ongoing) }\end{array}$ \\
\hline Fem & $\begin{array}{l}\text { Product: new-to-the-firm } \\
\text { Technologies could be leveraged and adapted } \\
\text { Production processes: new-to-the-firm }\end{array}$ & Internal & $\begin{array}{l}\text { Market: existing, but segment new-to-the-firm } \\
\text { Distribution channels: existing } \\
\text { Market approach: existing }\end{array}$ & Internal & $\begin{array}{l}\text { Success } \\
\text { (ongoing) }\end{array}$ \\
\hline \multicolumn{6}{|c|}{ Projects exploiting technological knowledge and exploring market knowledge } \\
\hline Drink & $\begin{array}{l}\text { Product: variation of existing } \\
\text { Technologies: leveraged and recombined } \\
\text { Production processes: existing }\end{array}$ & Internal & $\begin{array}{l}\text { Market: existing, but segment new-to-the-firm } \\
\text { Distribution channels: new-to-the-firm } \\
\text { Market approach: new-to-the-industry }\end{array}$ & Alliance & $\begin{array}{l}\text { Success } \\
\text { (ongoing) }\end{array}$ \\
\hline Air & $\begin{array}{l}\text { Product: existing } \\
\text { Technology: bought in license } \\
\text { Production processes: existing }\end{array}$ & $\begin{array}{l}\text { Internal, } \\
\text { technological license } \\
\text { bought }\end{array}$ & $\begin{array}{l}\text { Market: existing, but segment new-to-the-firm } \\
\text { Distribution channels: new-to-the-firm } \\
\text { Market approach: new-to-the-firm }\end{array}$ & Internal & $\begin{array}{c}\text { Stopped } \\
\text { (after } 5 \text { years) }\end{array}$ \\
\hline
\end{tabular}




\section{TABLE 2 Recommendations for managing NBD-projects}

1) Match the project's autonomy to the newness of required technological and market knowledge (see Figure 1). The more development of technological and market knowledge is required, the higher should be the project's autonomy.

2) Align project completion criteria with the development of technological and market knowledge. As the development of market knowledge continues after market introduction, these activities should be managed through projects until profitability is achieved (see Figures 1 and 2).

3) An organizational champion can be used to offset deficiencies in the project's autonomy and project completion criteria. However, management support from a champion is often not a sustainable solution due to managerial job rotation.

4) To speed up the development of market knowledge, projects can use strategic alliances with firms possessing complementary market knowledge.

5) Align sales force incentives with NBD-project requirements. Proactive sales force involvement and the development of new sales skills are essential for successfully commercialising NBD-projects that require new market knowledge. 


\section{References}

${ }^{1}$ C. W. L. Hill and F. T. Rothaermel, The performance of incumbent firms in the face of radical technological innovation, Academy of Management Review 28(2): 257-274 (2003).

${ }^{2} \mathrm{~J}-\mathrm{H}$. Ahn, D-J. lee and S-Y. Lee, Balancing business performance and knowledge performance of new product development: lessons from ITS industry, Long Range Planning 39: 525-542 (2006).

${ }^{3}$ See for example A. J. Shenhar, D. Dvir, O. Levy, and A.C. Maltz, Project success: a multidimensional strategic concept, Long Range Planning 34: 699-725 (2001); J. Lampel and P.P. Jha, Models of project orientation in multiproject organizations, P. W. G. Morris and J. K. Pinto, The Wiley guide to managing projects, John Wiley \& Sons, Hoboken (2004)

${ }^{4}$ J. J. P. Jansen, F. A. J. Van den Bosch and H. W. Volberda, Exploratory innovation, exploitative innovation, and performance: effects of organisational antecedents and environmental moderators, Management Science 52(11): 1661-1674 (2006); R.D. Dewar and J.E. Dutton, The adoption of radical and incremental innovations: an empirical analysis, Management Science 32(11): 1422-1433 (1986).

${ }^{5}$ U. De Brentani, Innovative versus incremental new business services: different keys for achieving success, Journal of Product Innovation Management 18: 169-187 (2001).

${ }^{6}$ E. Danneels, The dynamics of product innovation and firm competences, 23: 1095-1121 (2002). Several authors argued that NBD-projects could also benefit from available knowledge. H. Chesbrough, Designing corporate ventures in the shadow of private venture capital, California Management Review 42(3): 31-49 (2000); W.M. Cohen and D.A. Levinthal, Absorptive capacity: a new perspective on learning and innovation, Administrative Science Quarterly 35: 128-152 (1990).

${ }^{7}$ W. J Abernathy and K. B. Clark, Mapping the winds of creative destruction, Research Policy 14: 3-22 (1985); Danneels (2002) op. cit.

${ }^{8}$ D. Dougherty, A practice-centered model of organizational renewal through product innovation, Strategic Management Journal 13: 77-92 (1992).

${ }^{9}$ R. Garcia and R. Calantone, A critical look at technological innovation and innovativeness terminology: a literature review, Journal of Product Innovation Management 19: 110-132 (2002)

${ }^{10}$ C. Lechner and S.W. Floyd, Searching, processing, codifying, and practicing: key learning activities in exploratory initiatives, Long Range Planning 40: 9-29 (2007).

${ }^{11}$ R. G. McGrath, exploratory learning, innovative capacity and managerial oversight, Academy of Management Journal 44(1): 118-131 (2001)

${ }^{12}$ Danneels (2002) op. cit.

${ }^{13} \mathrm{~B}$. Kogut and U. Zander, Knowledge of the firm, combinative capabilities and the replication of technology, Organization Science 3: 383-397 (1992).

${ }^{14}$ J. G. March, Exploration and exploitation in organizational learning, Organization Science 2 (1): 71-87 (1991); M. J. Benner and M. L. Tushman, Exploitation, exploration, and process management: the productivity dilemma revisited. Academy of Management Review 28(2), 238-256 (2003).

${ }^{15}$ K.E. Söderquist, Organising knowledge management and dissemination in new product development: lessons from 12 global corporations, Long Range Planning 39: 497-523 (2006); D. Dougherty and C.H. Takacs, Team Play: heedful interrelating as the boundary for innovation, Long Range Planning 37: 569590 (2004).

${ }^{16}$ C. A. O’Reilly and M. T. Tushman, The ambidextrous organisation, Harvard Business Review April: 7481 (2004).

${ }^{17}$ M. Kodama, Knowledge creation through networked strategic communities: case studies on new product development in Japanese companies, Long Range Planning 38: 27-49 (2005); H. Scarbrough, J. Swan, S. Laurent, M. Bresnen L. Edelman and S. Newell, Project-based learning and the role of learning boundaries. Organization Studies 25(9): 1579-1600 (2004).

${ }^{18} \mathrm{M}$. Tripsas and G. Gavetti, Capabilities, cognition and inertia: evidence from digital imaging, Strategic Management Journal 21: 1147-1161 (2000).

${ }^{19}$ See the classic book of Wheelwright and Clark on managing NBD-projects and processes: S. C. Wheelwright and K. B. Clark, Revolutionizing product development: Quantum leaps to speed, efficiency and quality, The Free Press, New York (1992); K.M. Eisenhardt and B. N. Tabrizi, Accelerating adaptive processes: product innovation in the global computer industry, Administrative Science Quarterly 40: 84110 (1995); X.M. Song, R.J. Thieme and J. Xie, The impact of cross-functional joint involvement across product development stages: an exploratory study, Journal of Product Innovation Management 15: 289-303 
(1998); S. Hart, E. J. Hultink, N. Tzokas and H. Commandeur, Industrial companies' evaluation criteria in new product development gates, Journal of Product Innovation Management 20: 22-36 (2003).

${ }^{20}$ R. A. Burgelman, Designs for Corporate Entrepreneurship In Established Firms, California Management Review 6: 154-166 (1984); McGrath (2001) op. cit.

${ }^{21}$ J.K. Pinto and J.E. Prescott, Variations in critical success factors over the stages in the project life cycle, Journal of Management 14(1): 5-18 (1988); Song et al. (1998) op. cit.

${ }^{22}$ M. Schindehutte, M. H. Morris, and D. F. Kuratko, Triggering events, corporate entrepreneurship and the marketing function, Journal of Marketing Theory and Practice (spring): 18-30 (2000).

${ }^{23} \mathrm{R}$. A. Burgelman, Strategy as vector and the inertia of coevolutionary lock-in, Administrative Science Quarterly 47: 325-35 (2002); D. Leonard-Barton, Core capabilities and core rigidities: a paradox in managing new product development, Strategic Management Journal 13: 111-125 (1992)

${ }^{24}$ A.K. Gupta and V. Govindarajan, Knowledge flows within multinational corporations, Strategic Management Journal 21: 473-496 (2000)

${ }^{25}$ M. Sorrentino and M. L. Williams, Relatedness and corporate venturing: does it really matter? Journal of Business Venturing 10: 59-73 (1995)

${ }^{26}$ M. A. Schilling and C. W. L. Hill, managing the new product development process: strategic imperatives, Academy of Management Executive 12(3) 67-81 (1998); G. C. O’Connor and R. De Martino, Organizing for radical innovation: an exploratory study of the structural aspects of RI management systems in large established firms, Journal of Product Innovation Management 23: 475-497 (2006)

${ }^{27}$ Scarbrough et al. (2004) op. cit.; McGrath (2001) op. cit.

${ }^{28}$ Z. Block and I. C. MacMillan, Corporate Venturing. Boston: Harvard Business School Press (1993); R. A. Burgelman, Managing the new venture division: research findings and implications for strategic management, Strategic Management Journal 6: 39-54 (1985).

${ }^{29}$ Wheelwright and Clark (1992) op. cit.

${ }^{30}$ R.J. Calantone, K. Chan and A.S. Cui, Decomposing product innovativeness and its effects on new product success, Journal of Product Innovation Management 23(5): 408-421 (2006).

${ }^{31}$ Hill and Rothaermel (2003) op. cit.

${ }^{32}$ E. M. Olson, O. C. Walker Jr., R. W. Ruekert, J. M. Bonner, Patterns of cooperation during new product development among marketing, operations and R\&D: implications for project performance, Journal of Product Innovation Management 18: 258-271 (2001)

${ }^{33}$ Z. Emden, R.J. Calantone and C. Droge, Collaborating for new product development: selecting the partner with maximum potential to create value, Journal of Product Innovation Management 23: 330-341 (2006); J. S. Harrison, M. A. Hitt, R. E. Hoskisson, R. D. Ireland, resource complementarity in business combinations: extending the logic to organizational alliances, Journal of Management 27: 679-690 (2001); H.W. Chesbrough, Open innovation: the new imperium for creating and profiting from technology, Boston: Harvard Business School Press (2003).

${ }^{34}$ Wheelwright and Clark (1992) op cit.

${ }^{35}$ Pinto and Prescott (1988) op cit.

${ }^{36}$ S.A. Zahra, A.P. Nielsen, W.C. Bogner, Corporate entrepreneurship, knowledge, and competence development, Entrepreneurship Theory and Practice 23: 169-189 (1999).

${ }^{37}$ D. Milosevic, Managing new product development projects, P. W. G. Morris and J. K. Pinto, The Wiley guide to managing projects, John Wiley \& Sons, Hoboken (2004).

${ }^{38}$ See Thornhill and Amit for a discussion of these phases of the NBD-projects life-cycle and when each phase ends. S. Thornhill and R. Amit, A dynamic perspective of internal fit in corporate venturing. Journal of Business Venturing 16: 25-50 (2001).

${ }^{39}$ House and Price referred to this point in time as BEAR (Break-even-after-release). Their model shows that cumulative investments in a project do not increase after market introduction, suggesting they also view investments in exploration of market knowledge during the commercialisation phase as operational or business costs instead of project investments. C. H. House and R. L. Price, The return map: tracking product teams, Harvard Business Review (1): 92-100 (1991).

${ }^{40}$ See the works of Cooper on the activities involving an NBD-process: R.G. Cooper, Stage-gate system: a new tool for managing new products, Business Horizons 33(3): 44-54; Winning at new products:

accelerating the process from idea to launch, Addison-Wesley, Reading.

${ }^{41}$ U. Koners and K. Goffin, Learning from new product development projects: an exploratory study, Creativity and Innovation Management 14(4): 334-344 (2005) 
${ }^{42}$ See for a discussion on market activities during the development and the commercialisation phase: C. A. Di Benedetto, Identifying the key success factors in new product launch, Journal of Product Innovation Management 16: 530-544 (1999); P. Kotler, Marketing Management: analysis, planning, implementation and control $\left(\mathbf{9}^{\text {th }}\right.$ edition), Prentice Hall, Upper Saddle River. R. G. McGrath, T. Keil, and T. Tukiainen, Extracting value from corporate venturing, MIT Sloan Management Review, 48(1): 50-56 (2006)

43 e.g. Wheelwright and Clark (1992) op. cit.

${ }^{44}$ Adams and colleagues show how biases towards established routines favour an emphasis on technological knowledge and raise barriers for exploring market knowledge: M. E. Adams, G. S. Day, and D. Dougherty, Enhancing new product development performance: an organizational learning perspective, Journal of Product Innovation Management 15: 403-422 (1998)

${ }^{45}$ See for a discussion on launch strategies: S. Stremersch and G. J. Tellis, Understanding and managing international growth of new products, International Journal of Research in Marketing 21: 421-438 (2004) G. J. Tellis, S. Stremersch and E. Yin, The international takeoff of new products: the role of economics, culture and country innovativeness, Marketing Science 22(2): 188-208 (2003)

${ }^{46}$ A.K. Gupta and V. Govindarajan, Knowledge flows within multinational corporations, Strategic Management Journal 21: 473-496 (2000)

${ }^{47}$ See for example Burgelman (1984) op. cit., who suggested to align project autonomy to the degree of relatedness and strategic importance of the idea.

${ }^{48}$ Burgelman, Managing the internal corporate venturing process, Sloan Management Review 26: 33-48 (1984).

${ }^{49}$ L. Lindkvist, Knowledge communities and knowledge collectivities: a typology of knowledge work in groups, Journal of Management Studies 42(6): 1189-1210 (2005); L. Lindkvist, J. Söderlund and F. Tell, Managing product development projects: on the significance of fountains and deadlines, Organization Studies 19: 931-951 (1998).

${ }^{50}$ Several studies have pointed to the importance of organisational champions and sponsors for NBDprojects: P. G. Greene, C. G. Brush, M. M. Hart, The corporate venture champion: a resource-based approach to role and process, Entrepreneurship Theory and Practice 23: 103-122 (1999); S. L. Brown and K. M. Eisenhardt, Product development: past research, present findings, and future directions, Academy of Management Review 20(2): 343-378 (1995).

${ }^{51}$ D. Dougherty and C. Hardy, Sustained product innovation in large, mature organizations: overcoming innovation-to-organization problems, Academy of Management Journal 39(5): 1120-1153.

${ }^{52}$ Zemden et al. (2006) op. cit.

${ }^{53}$ See Hultink and Atuahene-Gima for a discussion of the consequences of disalignment of sales force incentives in the context of new product development. E.J. Hultink and K. Atuahene-Gima, The effect of sales force adoption on new product selling performance, Journal of Product Innovation Management 17: 435-450.

${ }^{54}$ X. M. Song and M.M. Montoya-Weiss, Critical development activities for really new versus incremental products, Journal of Product Innovation Management 15: 124-135 (1998).

${ }^{55}$ Danneels (2002) op. cit.

${ }^{56} \mathrm{M}$. Engwall, No project is an island: linking projects to history and context, Research Policy 32: 789-808 (2003).

${ }^{57}$ See the following articles for a discussion on the specificities of managing projects in the context of project-based organisations. J. Sydow, L. Lindkvist and R. DeFillippi, Project-based-organizations, embeddedness and repositories of knowledge: editorial, Organization Studies 29(5): 1475-1489 (2004); R. J. DeFillippi and M. B. Arthur, Paradox in pr0ject-based enterprise: the case of film-making, California Management Review 40(2); 125-139 (1998). The following articles provide a good reference point for projects dealing with complex products and systems. M. Hobday, The project-based organisation: an ideal form for managing complex products and systems, Research Policy 29: 871-893 (2000); D. M. Gann and A. J. Salter, Innovation in project-based, service-enhanced firms: the construction of complex products and systems, Research Policy 29: 955-972 (2000).

${ }^{58}$ K. M. Eisenhardt, Building Theories from Case Study Research, Academy of Management Review 14(4): 532-550 (1989); R. K. Yin, Case study research: design and methods, Sage Publications, Thousand Oaks, California (1994).

${ }^{59}$ B. R. Golden, Further remarks on retrospective accounts in organizational and strategic management research, Academy of Management Journal 40(5): 1243-1252 (1997). 
${ }^{60}$ See Tripsas and Gavetti (2000) for a more detailed description of the Polaroid case. 


\section{Publications in the Report Series Research ${ }^{*}$ in Management}

\section{ERIM Research Program: "Strategy and Entrepreneurship"}

2007

Longitudinal Study on the Performance of U.S. Pharmaceutical Firms: The Increasing Role of Marketing

L.H. Pattikawa

ERS-2007-020-STR

http://hdl.handle.net/1765/9400

The Impact of Corporate Venturing on a Firm's Competence Modes J. Henri Burgers, Frans A.J. Van Den Bosch and Henk W. Volberda ERS-2007-061-STR

http://hdl.handle.net/1765/10536

Why New Business Development Projects Fail: Coping with the Differences of Technological versus Market Knowledge J. Henri Burgers, Frans A.J. Van Den Bosch and Henk W. Volberda

ERS-2007-072-STR

* A complete overview of the ERIM Report Series Research in Management: https://ep.eur.nl/handle/1765/1

ERIM Research Programs:

LIS Business Processes, Logistics and Information Systems

ORG Organizing for Performance

MKT Marketing

F\&A Finance and Accounting

STR Strategy and Entrepreneurship 